the Bristol Channel and the Severn as far north as Tites Point, but inland the descriptions take in Frocester near Stroud, and thence southwards they include Bath, Bradford-on-Avon, Westbury, and the country near Frome, together with the Mendip Hills.

In this highly interesting district a great number of geological formations are met with from the Silurian to the Upper Oolites, with sundry igneous rocks, and Post-Tertiary deposits including those of caverns and raised beaches.

The story of the great physical changes indicated by the strata and associated volcanic rocks is briefly and pleasantly told in the Introduction by Professor Lloyd Morgan, whose essay touches on the poetic aspect of geology and is well calculated to stir up enthusiasm.

Then follow the practical instructions on excursions, aided by useful diagram-sections and maps, all indicative of the author's wide and excentional knowledge of petrography, stratigraphy, and palæontology.

Of late years special attention has been given to the Carboniferous Limestone, as well as to the volcanic rocks of Mendip and of the coast near Weston-super-Mare. The particulars given of the zonal divisions in the Carboniferous will be appreciated, but for the sake of the younger students it would have been well to indicate the classes of organisms to which belong such forms as Caninia. Seminula, Syringothyris, etc. The presence of arborescent markings in the Carboniferous Limestone is interesting; the author refers to them as 'Cotham Marble' bands, but here the use of the term Landscape Marble would have been better. Cotham Marble has its own horizon in the Rhætic Beds, and if there had been good local sections at Cotham the author would no doubt have guided us to them. He wisely, however, gives no account of temporary exposures. The famous section at Aust gives the best section of the strata. The Lias and Inferior Oolite also are seen in various noted localities, and those who are interested in hemere will find an enumeration of thirty-one for their guidance. They are, however, for the specialist, and the student will find the ordinary groupings duly indicated. The names Upper and Lower Lias might have been introduced on the Table II.

\title{
IX.-BrifF Notices.
}

1. Geological Map of Central Eukope.-A small colour-printed map of this region, on the scale of 100 miles to 1 inch, has been published by Mr. Stanford (1911), price 5s. It shows the leading geological systems and intrusive igneous rocks, under twelve tablets: Miocene and Pliocene, Eocene and Oligocene, Carboniferous and Permian, Upper Silurian and Devonian, being respectively grouped together. Certain pre-Cambrian or Archæan rocks are classed as 'Briorerian', which seems too local a term for such a map, while another tablet indicates "Crystalline schists and gneiss". 'The topography is clear, showing the rivers, mountains, and principal towns, but no railways, and the colours for the most part are distinctire, although here and there, in the smaller areas, numbers printed on map and tablets would have been an advantage. The map includes Dublin, Hull, and Kiel on the north, Warsaw and Belgrade on the east, Brindisi, northern 
Sardinia, and Madrid on the south. It will therefore prove a very handy guide to the geological traveller, and be useful also for general reference.

2. Mineralogy. By F. H. Hatch, Ph.D., etc. Fourth edition, entirely rewritten and enlarged. pp. ix +253 , with 124 illustrations. London: Whittaker \& Co., 1912. Price 4s. net.

ATER passing through three editions without change this little A manual has been entirely rewritten, and in its latest form is twice its original bulk. In the first part, dealing with the properties of minerals, the chapter on physical properties has been considerably enlarged, and a good account of the phenomenon of refraction is included. The use of a different notation for elasticity axes might have been preferred, however; confusion with the erystallographic axes may arise through the employment of small Old English characters of the same notation. It may be noted also that " statical changes", mentioned in connexion with pyro-electricity (p. 57), should evidently be read as "statical charges". A list of the more important mineral species, classified according to chemical composition, makes a useful addition.

A much fuller account of the rock-forming minerals is to be found in the second or descriptive portion, and the chapter on ores is almost three times its original size. Considerable attention seems to have been paid to the preparation of this book, and the student of elementary mineralogy would do well to provide himself with a copy.

3. Belemnitella mudronata Chalk of Smbirsk. -The geological library of the British Museum has received from the Ghornoi Institute of St. Petersburg a copy of the rare volume "Nauchno-istorich. Sbornik. - 1873", which contains Laghusen's paper on the B. mucronata chalk of Simbirsk, with its four beautiful plates. One might easily fancy oneself dealing with a typical Norwich fauna. Considering the Ghornoi Institute had but three copies of the work left, their action in presenting one to the British Museum (Nat. Hist.) is most generous. It is of much service and will be highly appreciated.

4. Topographic Map of Meekatharra, Western Australia.-This map, on the scale of 40 chains to an inch, and published br the Geological Survey of Western A ustralia, is the work of Mr. H. W.,B. Talbot, Assistant Field Geologist, and represents part of the Murchison Goldfield.

\section{REPORTS AND PEOCFEDINGS.}

I.-Geological Society of London.

February 28, 1912.-Dr. Aubrey Strahan, F.R.S., President, in the Chair.

The following communications were read :-

1. "Late Glacial and Post-Glacial Changes in the Lower Dee Valley." " By Leonard Johnston Wills, M.A., F.G.S, Fellow of King's College, Cambridge.

${ }^{1}$ Communicated by permission of the Director of H.M. Geological Survey. 